\title{
Aortic Coarctation Indicator
}

National Cancer Institute

\section{Source}

National Cancer Institute. Aortic Coarctation Indicator. NCI Thesaurus. Code C139033.

An indication as to whether there is coarctation of the aorta. 